\title{
Differences of Influence of Playing Playdough and Puzzles on Fine Motor Skills and Logical- Mathematical Intelligence in Early Childhood
}

\author{
Panggung Sutapa \\ Sport Science Study Program \\ Universitas Negeri Yogyakarta \\ Yogyakarta, Indonesia \\ panggung_s@uny.ac.id \\ Fatkhurahman Arjuna \\ Sport Science Study Program \\ Universitas Negeri Yogyakarta \\ Yogyakarta, Indonesia \\ arjuna@uny.ac.id
}

\author{
Yudik Prasetyo \\ Sport Science Study Program \\ Universitas Negeri Yogyakarta \\ Yogyakarta, Indonesia \\ yudik@uny.ac.id \\ Hadwi Prihatanta \\ Sport Science Study Program \\ Universitas Negeri Yogyakarta \\ Yogyakarta, Indonesia \\ hadwiprihatanta@gmail.com
}

\begin{abstract}
-playing at a tender age is part of life as playing could be a means of education. The purpose of this research is to determine the effect of playdough games and puzzles on fine motor skills and logical-mathematical intelligence in early childhood. The specimen in this study were children of Tunas Melati Kindergarten in Sleman regency 50 children were used for this experiment. The data was analyzed using a two -way ANOVA with significance level of 5\%. The results showed that (1) there was a significant effect of the playdough games and puzzles on fine motor skills with $P<0.05$, (2) there was a significant effect of playdough and puzzles on logicalmathematical intelligence with $P<0.05$, and (3) playdough had more influence on fine motor skills while puzzles had more influence on logical-mathematical intelligence with $P<0.05$. it was concluded that playdough and puzzles both influenced the improvement of fine motor skills and logical-mathematical intelligence but playdough had a greater influence on fine motor skills while puzzles had a greater influence on logicalmathematical intelligence.
\end{abstract}

Keywords—playing, playdough, puzzles, fine motor skills, intelligence in early childhood

\section{INTRODUCTION}

In order To encourage the potentials that exists in early childhood, there inside for continuous stimulation either by an instructor or the parents so that the baby can grow and develop very well. There are many things that can be used to stimulate children's potentials in music, linguistic, kinesthetic, soft and gross motor skills, mathematics, interpersonal and intrapersonal relationships. One of such ways is by playing. Playing with children is a necessity because playing is part of their lifestyle. It is something that cannot be removed from the life of a child. [1].children can spend all their energy, playing and trying to socialize with others. playing can be used to learn, it also aids them in developing motor skills. Children could play individually for instance, a child could play puzzles, playdough, meronce, folding and cutting etc. they could also play in groups like baseball, soccer, jamuran and gobak sodor.
The act of teaching using playdough and puzzles is rarely performed by kindergarten teachers because of the lack of knowledge on the children's part of the patterns involved in playing playdough and puzzles. Learning by using playdough and puzzles can be used to develop the finger skills of most children in their early childhood and it can also be used to develop their imagination.

The essence of Early childhood education is to develop, explore, and stimulate the childs' potentials at an early stage. . In the kindergartens, the childs' potentials are geared towards reading, writing and solving simple arithmetics. There are 10 diffierent kinds of abilities that could be developed or stimulated in children.

Formulation of the Problem (1) How does playdough and puzzles influence fine motor skills? (2) How does playdough and puzzles influence logical-mathematical intelligence? (3) Which of the games is more effective for developing fine motor skills and logical-mathematical intelligence?

Playdough can be played anywhere, in open space, behind closed doors, in the fields or in the hall. The materials that are used to make playdough are plasticine mixed with wheat and starch in equal proportions, a little quantity of water and stir to form the chewy material and then paint as desired. These materials can be used as a medium for learning or teaching children how to squeeze and mould different objects, animals, plants and some parts of plants like stems, leaves, flowers, branches, and fruits [2]. Playing is very helpful in terms of children's cognitive, affective, and psychomotor development [3]. Playing is an open ended process that allows the individuals involved to feel free to explore a wide range of possibilities with no pre-established rules in the procedures or outcomes. Being competent in playing means being self-directed, or self-defined .[4]. Development of motor skills in early childhood requires motivation from adults and this can be achieved through various media. [5] as stated by Semoglou early childhood education stimulated by appropriate media is helpful in the development of motor skills. The development of motor 
skills as early as possible through activities such as playing is helpful in achieving optimal development [7].

teaching children how to play puzzles can help them in identifying the geometry of objects, sizes, and how to pair objects in accordance with their shapes and sizes correctly and quickly.. In addition, the knowledge of puzzles also helps to stimulate a child's imaginative and logical reasoning. [9].

Playing of puzzles creates an avenue for the child to directly interact with the object and this allows the child to make use of his/her five senses to obtain facts used to solve the problems encountered. puzzles that involves matching of the right objects provides an avenue for the child to think concretely when dealing with direct and abstract objects thus this helps to develop a children's logical thinking . . a puzzle of rearranging a series of scattered pieces of images stimulates a child's intelligence, imagination and creativity.Motor skills are divided into two main parts: gross motor skills and fine motor skills. Gross motor skills is defined as those skills or things that have to do with physical activities whether locomotive, non locomotive, or manipulative. Gross motor skills are the basis for the fundamental development of fine motor skills. The development of gross motor starts when toddlers begin to crawl, walk, run, jump, and throw. It is in line with the theory that states that the basic motor skills consist of motor capabilities such as walking, rolling, crawling, running and jumping, which means body movement through space. [10]. The term physical motor includes both gross motor and fine motor. gross motor skills always comes first before the fine motor skills. Gross motor skills are from birth while the fine motor skills emerges the next few years after birth, this is as a result of the need for relatively more complicated coordination between nerves and muscles [11].

The theory from Ester Thelen states that the development of fine motor skills cannot be separated from the science of motion, performance body movement and this must perceive things that motivate and use the perception to refine its motion [12]. Motion behaviour can be divided into three parts, the first is the neural factor that affects motion, the second is the study of motion, and the third is the development of motion and this includes changes in behaviour. [13].

logical-mathematical intelligence is the ability to recognize numbers, classifications, compile, compare, and the ability to identify various shapes and sizes. The mathematical context focuses on numbers and operations, space and geometry, pattern/functions and informal measurement [14]. logicalmathematical intelligence is the ability to understand the concepts of logical-mathematics and structured thinking, and also being able to calculate, estimate, and recognize numbers with various series.

Hypothesis (1) playdough and puzzles have a great influence on fine motor skills. (2) they both influence logical-mathematical intelligence. (3) playdough can improve the fine motor skills, while puzzles can improve the logicalmathematical intelligence..

\section{RESEARCH METHODS}

\section{A. Research Type and Design}

This is experimental research and the data were analysed quantitatively in order to determine the effect of playing with playdough and puzzles on fine motor skills and logicalmathematical intelligence in early childhood.

\section{B. Research Approach}

The approach in the completion of this research is the effect of playing with playdough and puzzles on fine motor skills and logical-mathematical intelligence in early childhood.

\section{Research Setting}

The research was conducted in Tunas Melati Kindergarten in Sleman Regency, Yogyakarta Special Territory in February - June 2018.

\section{Definition of Operational Variable}

(1) Playing with playdough involves using the fingers to mould artificial objects such as animals, objects, plants etc by using materials from plasticine. (2) puzzles is done by fixing the seperate pieces of an image to form a whole picture. (3) Fine motor skills has to do with the ability of coordination between the eyes and fingers,for instance when asked to arrange bottles of coca cola into a model house 5, 4, $3,2,1$, coloring pictures and cutting patterned papers. (4) logical-mathematical intelligence is the ability of the child to group geometric objects either by size or by number which maybe odd or even.

\section{E. Research Instrument}

To obtain the data the research instruments used were in the following order :

\section{Fine motor skills:}

a. Arranging bottles of coca-cola into a model house 5, 4,3,2,1. (1) Arrangement of bottles within 2 minutes with none of them falling. scores 5. (2) Arranging the bottles within 3 - 4 minutes scores with all still standing erect 4. (3) Arranging bottles with none of the bottles falling and this should be done within 5-6 minutes scores 3. (4) Arranging bottles without the bottles falling within $7-8$ minutes scores 2. (5) Arranging all the bottles and all should be standing and this should be done in less than 9 minutes scores 1

b. Coloring images that should not pass through the colored fields. (1)Coloring the image without passing the colored field scores 5. (2) Coloring the image, going beyond 1-2 colored fields scores 4. (3) Coloring the image going beyond 3-4 colored fields scores 3. (4) Coloring the image going beyond 5-6 colored fields scores 2. (5) Coloring the image going beyond $<7$ colored fields scores 1

c. Cutting patterned paper. (1) Cutting the patterned paper exactly according to the image patterns scores 5. (2) Cutting the patterned paper not on 1st image pattern scores 4 . (3) Cutting the patterned paper not on 2nd image patterns scores 3. (4) Cutting the patterned paper not on 3rd image 
patterns scores 2. (5) Cutting the patterned paper not on $4^{\text {th }}$ image patterns scores 1

\section{The Logical-mathematical intelligence:}

a. Grouping objects based on geometric shapes. (1) Grouping all objects in the right geometrical shapes scores 5. (2) Grouping objects in the right geometrical shapes with 1 mistake scores 4. (3) Grouping objects in the right geometrical shapes with 2 mistakes scores 3. (4) Grouping objects in the right geometrical shapes with 3 mistakes scores 2. (5) Grouping objects in the right geometrical shapes with 4 mistakes scores 1

b. Grouping of objects by size. (1) Grouping all objects according to their appropriate sizes scores 5. (2) Grouping 4 objects according to their sizes correctly scores 4. (3) correctly Grouping 3 objects in accordance to their sizes scores 3. (4) Grouping 2 objects correctly according to their sizes scores 2 . (5) correctly Grouping 1 object by size scores 1

c. Grouping objects based on odd and even numbers. (1) Grouping all objects based on odd and even numbers scores 5. (2) Grouping 4 objects based on odd and even numbers scores 4. (3) Grouping 3 objects based on odd and even numbers scores 3. (4) Grouping 2 objects based on odd and even numbers scores 2. (5) Grouping 1 object based on odd and even numbers scores 1 .

\section{F. Data Analysis Techniques}

Data analysis technique used in this research was two-way ANOVA with a significance level of $5 \%$.

\section{RESULT}

\section{A. Description of Research Setting}

This research was conducted in Tunas Melati kindergarten in Sleman Regency from February to June 2018.

\section{B. Description of Research Subjects}

50 children of Class B in Tunas Melati Kindergarten in Sleman Regency..were used as specimen for this work

\section{Description of Data Analysis}

1. Test Results of Pre-requirement Analysis

- The normality test for data used in this study is Kolmogorov Smirnov, with the help of SPSS 20.0 for windows. Based on the statistical analysis conducted, the normality test indicates that $\mathrm{P}>0.05$. This indicates that the data distribution is normal.

- The result of homogeneity test indicates that $\mathrm{P}>0.05$. This depicts that the data in this study is homogeneous in other words the population has a common variance or homogeny.

\section{Results of Hypothesis Testing}

- The first hypothesis states that playing with playdough and puzzles has an influence on the fine motor skills. The results of the analysis determine that playing with playdough and puzzles improved the fine motor skills with $\mathrm{P}<0.05$. Thus, the research hypothesis is perceived to be significant ..

- The second hypothesis states that playing with playdough and puzzles has an influence on the logical-mathematical intelligence. The result of the research data analysis proved that $\mathrm{P}<0.05$, thus the research hypothesis was also seen to be significant .

- The third hypothesis states that playing with Playdough has more effect on fine motor skills than puzzles, while puzzles have more effect on logicalmathematical intelligence and this was noted to be significant with $\mathrm{P}<0.05$.

\section{DISCUSSION}

The development of fine motor skills and logicalmathematical intelligence needs to be done as early as possible. this is because the development of motor skills and logical-mathematical intelligence requires long concentration (15). A 4-year-old child that do not have good fine motor skills needs assistances in order to be able to coordinate the visual and motor movements, which involves the coordination of the eyes, fingers, and feet (11). Mathematical-logical intelligence is the ability to use numbers well and logically. This includes sensitivity to patterns and logical relationships, statements and propositions (if-then, causation), logical functions, and other abstractions. The processes used in logical-mathematical intelligence include: categorization, classification, conclusion, generalization, calculation, and hypothesis testing. Motor skills as well as logical-mathematical intelligence requires to be stimulated as this was is determined in this study where it was explained that playing games such as playdough and puzzles helps improve both motor skills and logicalmathematical intelligence. games like playdough had more significant effect on motor skills than games of puzzles. playdough helps the child focus his/her attention on the coordination between his/her eyes and fingers. On the other hand, puzzles had a significant effect on logicalmathematical intelligence. This is because puzzles gives children the opportunity to start to recognize and distinguish the various forms of geometry shape, and size) and sequence of numbers.

\section{CONCLUSION}

1. The games of playdough and puzzles have a significant effect on fine motor skills with $\mathrm{P}>0.05$

2. The games of playdough and puzzles also influences logical-mathematical intelligence with $\mathrm{P}>0.05$.

3. Based on the differences in mean values, it can be concluded that the games of playdough can improve fine motor skills more than games of puzzles while puzzles can improve logical-mathematical intelligence more than playdough. 


\section{REFERENCES}

[1] C. Macintyre, Play for children with special needs. New York. Routledge. 2010.

[2] D. Koralek, Learning through experience. Journal of National Association for the Education of Young Children (NAEYC). 2010. http://www.jstor.org/stable/42730533.

[3] A. K. Behrn, S. Roger. \& C. Mickan, A Comparison of the play skills of preschool children with and without developmental coordination disolder, Amarican Occupational. Therapy Foundation. 2001. 33. 198208

[4] E. Jones, R. M. Cooper, Playing get to smart. New York: Teachers College. 2006.

[5] I. Spanaki, "Graphomotor skills of greek kindergarten and elementary school children: Effect of a fine motor intervention program," Journal of Innovative Teaching.2014). Volume 3, Article 2. http://www.amsciepub.com/doi/pdf/10.2466/01.09/IT.3.2

[6] K. Semoglou, A. Alevriadou, \& A. Tsapakidou, "Grooss motor and fine motor skills the case of roma' Journal of European Psychomotricity," 2008 http://www.psychomotor.gr/images/stories/journal/volume1/specialIssue
[7] S. John, Factoring in fine motor: How improving fine motor abilities impacts reading and writing. Journal of Illionis Reading Council. 2013. Vol. 41, No 4

[8] A. Nugraha, dan N. Ratnawati, Kiat merangsang kecerdasan anak. Jakarta. Puspa Swara, 2003.

[9] P. G. Madrona, J. R. Iniesta, A. I. G. Espinosa, "Intervention guidelines on teaching social and motor skills in kindergarten. American journal of sports Science and Medicine," 2014. Vol 2. No, 6A, 9-12 Available online at http://pubs.sciepub.com/ajssm/2/6A/3

[10] S. Balasubramanian, Siddegowda. Family and child correlates of motor development of toddlers in India. International Journal Current Research and Review. Januari 2013, Vol 05 (02)

[11] J. W. Santrock, Life-span development, terjemahan Juda Damanik dan Achmad Chusairi. Jakarta. Erlangga, 2012.

[12] H. Rahyubi, Teori-teori belajar dan aplikasi pembelajaran motorik deskripsi dan tinjauan kritis. Bandung Nusa Media, 2012.

[13] M. Boivin, and K. L. Bierman, Promoting school readiness and early learning. United of America: Guilford Publications. 2014.

[14] T. Liu, H. Michelle, S. Sean, Motor Proficiensy of the head start and typically developing children on MABC-2. Journal of Child \& Adolencent Hehavio, 2015, 3 (2), 1-4. 